\title{
Vitamin D Receptor Gene Polymorphism In Chronic Telogen Effluvium; A Case-Control Study
}

This article was published in the following Dove Press journal:

Clinical, Cosmetic and Investigational Dermatology

\author{
Iman Seleit ${ }^{\prime}$ \\ Ola A Bakry' \\ Eman Badr ${ }^{2}$ \\ Eman $\mathrm{H}$ Hassan (iD) \\ 'Department of Dermatology, Andrology \\ and STDs, Faculty of Medicine, Menoufiya \\ University, Menoufiya Governorate, \\ Egypt; ${ }^{2}$ Department of Medical \\ Biochemistry, Faculty of Medicine, \\ Menoufiya University, Menoufiya \\ Governorate, Egypt
}

Correspondence: Ola A Bakry Department of Dermatology, Andrology and STDs, Faculty of Medicine, Menoufiya University, Shibeen El Koom, Menoufiya

Governorate 32817, Egypt

Tel +201065190509

Email olabakry8@gmail.com
Background: Telogen effluvium (TE) is a form of alopecia characterized by diffuse hair shedding. Vitamin D receptor (VDR) plays a role in hair cycle regulation as it is expressed in follicular keratinocytes and dermal papilla cells.

Purpose: To investigate the association between Cdx1 and Taq1 VDR gene polymorphisms and chronic TE.

Methods: Thirty female patients with chronic TE were selected and 30 healthy, age- and sex-matched volunteers were included as a control group. Detection of VDR gene polymorphisms Taq1 and Cdx1 was done by real-time polymerase chain reaction.

Results: Regarding Taq 1, CC genotype was present in $30 \%$ of cases versus $3.3 \%$ of controls. TC genotype was present in $33.3 \%$ of cases and $36.7 \%$ of controls. CC genotype was significantly associated with cases $(\mathrm{P}=0.01)$. It increases the risk of chronic TE by 14.7 folds. $\mathrm{C}$ allele was significantly associated with patient group $(\mathrm{P}=0.004)$. It increases the risk of disease occurrence by 3.1 folds. Regarding Cdx1, AA genotype was present in $6.7 \%$ of cases versus $3.3 \%$ of controls. GA genotype was present in approximately $30 \%$ of cases and $6.7 \%$ of controls. GA genotype was significantly associated with cases $(\mathrm{P}=0.03)$. It increases the risk of chronic TE by 6.3 folds. A allele was significantly associated with patient group $(\mathrm{P}=0.007)$. It increases the risk of disease occurrence by 3.8 folds.

Limitations: The main limitation is the small number of cases due to the time and financial constraints. Only chronic TE was analyzed, therefore, other types should be investigated in the following studies.

Conclusion: After exposure to primary physical or mental stressor, hair follicles are stimulated to enter prematurely into telogen and shed out. In individuals with Taq1 and Cdx1 polymorphisms, the disease persists as a result of prevention of new anagen growth and inhibition of hair follicle stem cell proliferation.

Keywords: telogen effluvium, VDR, gene, polymorphism

\section{Introduction}

Telogen effluvium (TE) is a form of non-scarring alopecia characterized by diffuse hair shedding. ${ }^{1}$ A wide variety of potential triggers have been implicated in its pathogenesis. The follicle tends to be in premature termination of anagen irrespective of the cause of hair loss. Later, the follicle precipitates into catagen and transforms into resting stage mimicking telogen. ${ }^{2}$ TE can be acute (lasting for less than 6 months), chronic ( 6 months or more), or chronic-repetitive. ${ }^{3}$ For unknown reasons, chronic TE affects only females. ${ }^{4,5}$

Vitamin D mediates its action in the body through vitamin D receptor (VDR) that modulates the transcription of target genes which help in calcium uptake or bone formation. ${ }^{6}$ 
VDR interacts with the promoters of vitamin-D-responsive genes. The human VDR protein contains either 427 or 424 amino acids depending upon the presence of a $\mathrm{T}$ to $\mathrm{C}$ polymorphism (ATG to ACG) in a translational start site. ${ }^{7}$ VDR is expressed in the two major cell populations that make up the hair follicle: the mesodermal dermal papilla cells and the epidermal keratinocytes. VDR expression in the hair follicle is increased during late anagen and catagen, correlating with decreased proliferation and increased differentiation of keratinocytes. ${ }^{8}$

The role of VDR in the hair cycle was first suggested by the observation of alopecia in patients with type IIA vitamin D-dependent rickets. ${ }^{9}$ It has been proposed that normal function of VDR is essential for initiation of the first post-natal hair cycle. ${ }^{10}$ In addition, it was reported that forceful induction of catagen by hair plucking results in failure of new anagen hair formation in VDR-deficient mice. So, VDR is essential for the start of new anagen. ${ }^{11}$

VDR is important also in regulating the growth cycle of mature hair follicles. Certain mutations in the VDR lead to misregulated gene expression resulting in aberrant hair follicle cycling and alopecia. ${ }^{12}$ Despite these important functions of VDR in hair follicle biology, its gene polymorphism was not extensively studied in hair disorders. It was investigated in alopecia areata with lack of association between polymorphism and disease risk. ${ }^{13,14}$

Previous studies reported that serum vitamin D2 levels in females with TE were significantly lower than in healthy controls. These levels decreased with increased disease severity. So, vitamin D deficiency can be a significant factor for TE development. ${ }^{15,16}$ Mysore et al recommended measurement of serum vitamin D level in cases of TE and vitamin D supplement as a treatment of these cases. ${ }^{17}$ However, there is no published data about any clinical trial testing the effect of vitamin D in TE treatment.

The relationship between VDR gene polymorphism and vitamin $\mathrm{D}$ level is a matter of controversy. Some authors reported lack of association between polymorphism and vitamin level. ${ }^{18}$ Others reported negative correlation between risky genotypes and vitamin level but the underlying molecular mechanism is not exactly known. ${ }^{19}$

Several VDR single-nucleotide polymorphisms (SNPs) have been identified that may deregulate vitamin D activity, interfering with its role and increase the risk of hair loss. ${ }^{20}$ $\mathrm{Cdx}-1$ polymorphism is $\mathrm{A} / \mathrm{G}$, transition substitution of $\mathrm{Cdx}-1$ binding site on VDR gene. It is rs $731236 .^{21}$ The TaqI polymorphism is a $\mathrm{T} / \mathrm{C}$ nucleotide substitution (ATT to ATC) leading to a synonymous change at codon 352 (isoleucine) in exon IX. ${ }^{6}$

The aim of this study was to investigate the association between Cdx1 and Taq1 VDR gene polymorphism and chronic TE to explore if these polymorphisms affect the disease occurrence or influence its clinical presentation.

\section{Materials And Methods}

This case-control study was conducted on 30 female patients with chronic TE and 30 age- and sex-matched healthy volunteers who have no present or past history of chronic TE as a control group. Both groups carry the same ethnic background.

The study protocol was approved by the Ethical Research Committee and Committee of Human Rights in Research in Menoufiya Faculty of Medicine.

Cases were selected from the dermatology outpatient clinic during the period from April 2016 to October 2016. Control subjects were selected from healthy hospital staff.

A written consent form approved by the Local Ethical Research Committee was taken from every participant before the study initiation.

\section{Inclusion Criteria}

All cases of chronic TE were included based on:

1. History of persistent increased hair shedding for $>6$ months associated with periodic fluctuations, without widening of the central part.

2. Examination:

I. General examination to exclude systemic causes of hair loss.

II. Dermatological examination:

a. Examination of shed or pulled hairs with the naked eye clarified a depigmented bulb.

b. Scalp examination showed loss of $<50 \%$ of scalp hair.

c. Thinning of hair all over the scalp, or bitemporal hair thinning.

d. Positive hair pull test in $>1$ scalp region.

The hair pulls were performed at the vertex, 2 parietal areas, and the occipital area of the scalp. Next, the pulled hairs were counted. Any broken hairs that were extracted from the bundle during the pull were discarded. If more than $10 \%$ of the hairs in each bundle are removed from a scalp area, the hair pull test was considered positive. If fewer than $10 \%$ were removed, then the hair loss can usually be attributed to 
normal shedding. If a test was positive in more than one scalp region, TE was considered. ${ }^{22}$

(III) Trichoscopic examination: normal

Trichoscopic examination was done also for control subjects.

(IV) Chronic TE was differentiated from its main simulators; female pattern hair loss, psychogenic pseudoeffluvium, and diffuse alopecia areata (incognita). ${ }^{23}$

\section{Exclusion Criteria}

Any case or control subject with any one or more of the following was excluded:

- Systemic and/or scalp disease that might be related to hair loss.

- Medication associated with alopecia (eg, anticoagulants, retinoids, anticonvulsants, and antidepressants).

- Drugs containing vitamin D or dietary supplements.

- Menopausal, pregnant, and lactating females.

- Skin diseases other than chronic TE.

Clinical data describing patients' age, age of onset, disease duration, and family history were all documented.

\section{Every Case And Control Subject Underwent}

1. Laboratory investigation to exclude other causes of hair loss: T3, T4, TSH, CBC, serum iron, serum ferritin, serum zinc, ESR, ANA, and anti doublestranded DNA.

2. Detection of VDR gene polymorphism, SNP genotyping, for Cdx 1 rs731236 and Taq1 rs3776082 by real-time PCR.

Genomic DNA was extracted from frozen EDTA-treated blood sample using Gene JET ${ }^{\text {TM} W h o l e ~ B l o o d ~ G e n o m i c ~}$ DNA Purification Mini Kit (THERMO SCIENTIFIC, EU/Lithuania).

The DNA extract was used for SNP assay in a total reaction volume of $20 \mu \mathrm{L}$ with $10 \mu \mathrm{L}$ of TaqMan Genotyping Master Mix, $1.25 \mu \mathrm{L}$ of $20 \times$ TaqMan genotyping assay kits containing both primers and probes and nuclease-free water.
By using the 7500 Real-time PCR system (Applied Biosystems, Foster City, CA, USA), the Reaction steps were as follows: $50^{\circ} \mathrm{C}$ for 2 mins Pre-PCR read, then $95^{\circ} \mathrm{C}$ for 10 mins and 40 cycles of $95^{\circ} \mathrm{C}$ for $15 \mathrm{~s}, 60^{\circ} \mathrm{C}$ for $1 \mathrm{~min}$ (cycling), and $60^{\circ} \mathrm{C}$ for $1 \mathrm{~min}$ (Post-PCR).

The probe sequence for Cdx1 SNP rs731236:

TGGACAGGCGGTCCTGGATGGCCTC[T/C]ATCAG CGCGGCGTCCTGCACCCCAG The probe sequence for Taq1 SNP rs3776082:

GGCCCCTTACAGAGCACTTTCTTAC[A/G] TATGGGTGGGCTGAAATCCACATCT

\section{Statistical Analysis}

Data were collected, tabulated, and statistically analyzed using a personal computer with "(SPSS) version 11" program (SPSS Inc., Chicago, IL, USA). Fisher's exact test was used for comparison of qualitative variables in $2 \times 2$ tables when expected cell count of more than $25 \%$ of cases was less than 5 . Chi-square test $\left(\chi^{2}\right)$ was used to study the association between two qualitative normally distributed variables. Mann-Whitney $U$-test was used for comparison between two groups not normally distributed having quantitative variables. Odds ratio was used to describe the probability that people who are exposed to a certain factor will have a disease compared to people who are not exposed to the factor. Differences were considered statistically significant with $\mathrm{P}<0.05$.

\section{Results}

Patients' ages ranged from 19 to 44 years with a mean \pm SD of $29.83 \pm 7.65$ years and a median age of 28.5 years. The control group ages ranged from 19 to 44 years with a mean $\pm \mathrm{SD}$ of $29.93 \pm 6.60$ years and a median age of 29 years.

Clinical data of selected cases and control subjects are summarized in Table 1.

Trichoscopic examination was normal in all cases and all control subjects.

Regarding Taq1 polymorphism, TT genotype was more prevalent among control group than telogen patients $(60 \%$ versus $36.7 \%$ ). CC genotype was present in $30 \%$ of cases versus $3.3 \%$ of controls. TC genotype was present in $33.3 \%$ of cases and $36.7 \%$ of controls (Table 2 ).

$\mathrm{CC}$ genotype was significantly associated with cases $(\mathrm{P}=0.01)$. It increases the risk of $\mathrm{TE}$ by 14.7 folds while TC genotype increases the risk of occurrence by 1.4 folds (Table 2). 
Table I Clinical Data Of Selected Cases

\begin{tabular}{|c|c|c|c|c|c|c|}
\hline Variable & \multicolumn{2}{|c|}{ Cases $(n o=30)$} & \multicolumn{2}{|c|}{ Controls $(\mathrm{no}=30)$} & & P-value \\
\hline Age (years) & \multicolumn{2}{|c|}{$19-44$} & \multicolumn{2}{|c|}{$19-45$} & $\mathrm{t}=0.852$ & 0.398 \\
\hline Min-Max & \multicolumn{2}{|c|}{$29.83 \pm 7.65$} & \multicolumn{2}{|c|}{$29.93 \pm 6.60$} & & \\
\hline Mean $\pm S D$ & \multirow{2}{*}{\multicolumn{2}{|c|}{28.5}} & \multirow{2}{*}{\multicolumn{2}{|c|}{29.0}} & & \\
\hline Median & & & & & & \\
\hline Age of onset & \multicolumn{2}{|c|}{$18.40-43.10$} & \multicolumn{2}{|c|}{$\longrightarrow$} & $\longrightarrow$ & $\longrightarrow$ \\
\hline Min-Max & \multicolumn{2}{|c|}{$28.91 \pm 7.69$} & & & & \\
\hline Mean $\pm S D$ & \multirow{2}{*}{\multicolumn{2}{|c|}{27.60}} & & & & \\
\hline Median & & & & & & \\
\hline \multirow{4}{*}{$\begin{array}{l}\text { Duration of hair loss (months) } \\
\text { Min-Max } \\
\text { Mean } \pm \text { SD } \\
\text { Median }\end{array}$} & \multirow{3}{*}{\multicolumn{2}{|c|}{$\begin{array}{l}7.0-20.0 \\
11.60 \pm 3.75 \\
10.0\end{array}$}} & \multicolumn{2}{|c|}{$\longrightarrow$} & \multirow[t]{4}{*}{$\longrightarrow$} & \multirow[t]{4}{*}{$\longrightarrow$} \\
\hline & & & & & & \\
\hline & & & & & & \\
\hline & $\mathrm{No}$ & $\%$ & No & $\%$ & & \\
\hline Family history & \multirow{3}{*}{$\begin{array}{l}19 \\
11\end{array}$} & 63.3 & \multirow{3}{*}{$\begin{array}{l}28 \\
2\end{array}$} & \multirow{3}{*}{$\begin{array}{l}93.3 \\
6.7\end{array}$} & \multirow{3}{*}{$\begin{array}{l}2 \\
7.9\end{array}$} & \multirow[t]{3}{*}{0.004} \\
\hline Negative & & 36.7 & & & & \\
\hline Positive & & & & & & \\
\hline Hair pull test & \multirow{3}{*}{$\begin{array}{l}0 \\
30\end{array}$} & 0.0 & 30 & 100.0 & 2 & $<0.0001$ \\
\hline Negative & & 100.0 & \multirow[t]{2}{*}{0} & \multirow[t]{2}{*}{0.0} & \multirow[t]{2}{*}{200} & \\
\hline Positive & & & & & & \\
\hline
\end{tabular}

$\mathrm{T}$ allele was more prevalent among control than patient group $(78.3 \%$ versus $53.3 \%)$. C allele was significantly associated with patient group (46.7\% versus $21.7 \%$ ) $(\mathrm{P}=0.004)$. It increases the risk of disease occurrence by 3.1 folds (Table 2).

Regarding Cdx-1 polymorphism, GG genotype was more prevalent among control group than TE patients (90\% versus $63.3 \%$ ). AA genotype was present in $6.7 \%$ of cases versus $3.3 \%$ of controls. GA genotype was present in about $30 \%$ of cases and about $6.7 \%$ of controls. GA genotype was significantly associated with cases $(\mathrm{P}=0.03)$. It increases the risk of TE by 6.3 folds. AA genotype increases the risk of chronic TE by 2.8 folds (Table 2).

$\mathrm{G}$ allele was more prevalent among control than patient group $(93.3 \%$ versus $78.3 \%)$. A allele was significantly associated with patient group $21.7 \%$ versus $6.7 \%$ $(\mathrm{P}=0.007)$. It increases the risk of occurrence by 3.8 folds (Table 2).

There was no significant association between Taq 1 genotypes or alleles and clinical data of the studied cases (data not shown in tables or figures).

There was no significant association between Cdx 1 genotypes or alleles and clinical data of the studied cases (data not shown in tables or figures).

\section{Discussion}

In the present study, CC and TC genotypes of Taq 1 were significantly higher in chronic TE patients, compared with control group. They increase the risk of occurrence by 14.7 and 1.4 folds, respectively. C allele was significantly associated with patient group. It increases the risk of disease occurrence by about 3 folds.

TaqI polymorphism, located near the 3 '-UTR of the VDR gene, does not alter the protein's amino acid sequence. Therefore, it remains difficult to explain how this variant might influence VDR function. However, even if it does not have a direct action, it can be in linkage with other gene polymorphisms. Additionally, it may act as a marker of other sequences in the VDR gene that regulate transcription, translation, or RNA processing. ${ }^{24}$ It was reported that the 3'UTR of the gene is known to be involved in regulation of expression, especially through regulation of mRNA stability. ${ }^{25}$

It was also postulated that VDR polymorphisms could be functional themselves and affect the transcriptional activity of the VDR. ${ }^{26}$

As VDR is important in anagen initiation, we can postulate that VDR polymorphism Taq1 may be involved in persistence rather than initiation of chronic TE through prevention of new anagen growth after telogen shedding due to its effect on RNA 
Table 2 Prevalence Of VDR Genotypes And Alleles In Studied Groups

\begin{tabular}{|c|c|c|c|c|c|c|c|}
\hline & \multicolumn{2}{|c|}{ Cases $(n=30)$} & \multicolumn{2}{|c|}{ Control $(n=30)$} & \multirow[t]{2}{*}{$\mathbf{P}$} & \multirow[t]{2}{*}{ OR } & \multirow[t]{2}{*}{$95 \% \mathrm{Cl}$} \\
\hline & No. & $\%$ & No. & $\%$ & & & \\
\hline \multicolumn{8}{|c|}{ Taq I genotypes } \\
\hline TT & 11 & 36.7 & 18 & 60.0 & $\mathrm{P}=0.0 \mathrm{I}^{*}$ & & \\
\hline TC & 10 & 33.3 & 11 & 36.7 & & $\mathrm{I} .488$ & $0.48-4.64$ \\
\hline $\mathrm{CC}$ & 9 & 30.0 & I & 3.3 & & 14.727 & $1.63-132.64$ \\
\hline \multicolumn{8}{|c|}{ Allele frequency } \\
\hline $\mathrm{T}$ & 32 & 53.3 & 47 & 78.3 & $\mathrm{P}=0.004 *$ & - & \\
\hline C & 28 & 46.7 & 13 & 21.7 & & 3.164 & $1.426-7.016$ \\
\hline \multicolumn{8}{|c|}{ Cdx-I genotypes } \\
\hline GG & 19 & 63.3 & 27 & 90.0 & $\mathrm{P}=0.037^{*}$ & - & - \\
\hline GA & 9 & 30.0 & 2 & 6.7 & & 6.395 & $1.24-32.99$ \\
\hline AA & 2 & 6.7 & 1 & 3.3 & & 2.842 & $0.24-33.64$ \\
\hline \multicolumn{8}{|c|}{ Allele frequency } \\
\hline G & 47 & 78.3 & 56 & 93.3 & $\mathrm{P}=0.007^{*}$ & - & _- \\
\hline A & 13 & 21.7 & 4 & 6.7 & & 3.872 & $1.18-12.67$ \\
\hline
\end{tabular}

Note: *Significant.

stability, a conclusion that needs further investigation to be proved or denied.

As regard to $\mathrm{Cdx} 1$ polymorphism, AA and GA genotypes increase the risk of chronic TE by 2.8 and 6.3 folds, respectively. A allele was significantly associated with patient group. It increases the risk of disease occurrence by 3.8 folds.

It has been hypothesized that the role of the VDR in the hair cycle is to repress the expression of gene(s) in a ligand-independent manner. ${ }^{27}$ Mutations in the VDR that disrupt the ability of the unliganded VDR to suppress gene transcription are hypothesized to lead to the derepression of some gene(s). Products of those de-repressed genes, when expressed inappropriately, disrupt the hair cycle that ultimately leads to alopecia. Potential candidates include inhibitors of the Wnt signaling pathway. ${ }^{28}$

Cdx-1 is the direct transcriptional target of the Wnt signaling pathway ${ }^{29}$ and Wnt signaling in gut requires the binding of the Tcf4/ $\beta$-catenin complex to $\mathrm{Cdx}-1$ gene promoter, which induces the expression of $\mathrm{Cdx}-1 .{ }^{30}$ Scientists have found strong evidence that Wnt signaling is a crucial component in the maintenance of hair follicle stem cells (HFSCs). ${ }^{31}$ This finding overturns the previous assumption that Wnt signaling has a negligible impact on the maintenance of HFSCs, and is only critical in activating their proliferation for hair growth. ${ }^{32}$
Unlike most other tissue stem cells, that are dependent on sustaining signals from adjacent niche stem cells, HFSCs can maintain their stemness and growth potential by producing their own Wnt signals. Disrupting Wnt signaling caused the HFSCs to lose their stemness, with the hair follicle arrested in the telogen phase and no growth observed. ${ }^{31}$ Therefore, we can assume that Cdx-1 polymorphism may lead to the release of VDR suppressor action on inhibitors of Wnt signaling which adversely affect HFSCs and may share in chronic TE pathogenesis.

\section{Conclusions}

Based on the above-mentioned findings, we can suggest that, after exposure to primary physical or mental stressor, hair follicles are stimulated to enter prematurely into telogen and shed out. In individuals with Taq1 and Cdx1 polymorphisms, the disease persists as a result of prevention of new anagen growth and inhibition of HFSCs proliferation. Therefore, future genetic interference in affected patients may help in treatment of resistant cases.

\section{Disclosure}

The authors have no conflicts of interest that are directly relevant to the content of this study. 


\section{References}

1. Ozlu E, Karadag AS. Telogen effluvium. In: Kutlubay Z, Serdaroglu S, editors. Hair and Scalp Disorders. 7th ed. China: InTech; 2017:198-203.

2. Malkud S. Telogen effluvium: a review. J Clin Diagn Res. 2015;9: WE01-3. doi: 10.7860/JCDR/2015/15219.6492

3. Phillips TG, Slomiany WP, Allison R. Hair loss: common causes and treatment. Am Fam Physician. 2017;96:371-378.

4. Fatani MI, Binmahfoz AM, Mahdi AH, et al. Prevalence and factors associated with telogen effluvium in adult females at Makkah region, Saudi Arabia. J Dermatol Surg. 2015;19:27-30. doi:10.1016/j. jdds.2014.04.002

5. Whiting DA. Chronic telogen effluvium. Dermatol Clin. 1996;14:723731.

6. Bhanushali AA, Lajpal N, Kulkarni SS, Chavan SS, Bagadi SS, Das BR. Frequency of fokI and taqI polymorphism of vitamin D receptor gene in Indian population and its association with 25-hydroxyvitamin D levels. Indian J Hum Genet. 2009;15:108-113. doi:10.4103/09716866.60186

7. Malloy PJ, Feldman D. The role of vitamin D receptor mutations in the development of alopecia. Mol Cell Endocrinol. 2011;347:90-96. doi:10.1016/j.mce.2011.05.045

8. Demay MB, MacDonald PN, Skorija K, Dowd DR, Cianferotti L, Cox M. Role of the vitamin D receptor in hair follicle biology. $J$ Steroid Biochem Mol Biol. 2007;103:344-346. doi:10.1016/j. jsbmb.2006.12.036

9. Brooks MH, Bell NH, Love L, et al. Vitamin-D-dependent rickets type II: resistance of target organs to 1, 25-dihydroxyvitamin D. $N$ Engl $J$ Med. 1978;298:996-999. doi:10.1056/NEJM197805042981804

10. Bergman R, Schein-Goldshmid R, Hochberg Z, Ben-Izhak O, Sprecher E. The alopecias associated with vitamin D- dependent rickets type IIA and with hairless gene mutations: a comparative clinical, histologic, and immunohistochemical study. Arch Dermatol. 2005;141:343-351. doi:10.1001/archderm.141.3.343

11. Kong J, XJ L, Gavin D, Jiang Y, Li YC. Targeted expression of human vitamin $\mathrm{D}$ receptor in the skin promotes the initiation of the postnatal hair follicle cycle and rescues the alopecia in vitamin D receptor null mice. $J$ Invest Dermatol. 2002;118:631-638. doi:10.1046/j.1523-1747.2002.01727.x

12. Sakai Y, Demay MB. Evaluation of keratinocyte proliferation and differentiation in vitamin D receptor knockout mice. Endocrinol. 2000;141:2043-2204. doi:10.1210/endo.141.6.7515

13. Akar A, Orkunoglu FE, Tunca M, Taştan HB, Kurumlu Z. Vitamin D receptor gene polymorphisms are not associated with alopecia areata. Int J Dermatol. 2007;46:927-929. doi:10.1111/j.1365-4632.2007. 03140.x

14. Akar A, Orkunoglu FE, Ozata M, Sengul A, Gur AR. Lack of association between vitamin D receptor FokI polymorphism and alopecia areata. Eur J Dermatol. 2004;14:156-158.

15. Rasheed H, Mahgoub D, Hegazy R, et al. Serum ferritin and vitamin d in female hair loss: do they play a role? Skin Pharmacol Physiol. 2013;26:101-107. doi:10.1159/000346698
16. Gerkowicz A, Chyl-Surdacka K, Krasowska D, Chodorowska G. The role of vitamin D in non-scarring alopecia. Int J Mol Sci. 2017;18: E2653. doi:10.3390/ijms18122653

17. Mysore V, Parthasaradhi A, Kharkar RD, et al. Expert Consensus on the Management of Chronic Telogen Effluvium in India. Int $J$ Trichol. 2019;11:107-112.

18. Li K, Shi Q, Yang L, et al. The association of vitamin D receptor gene polymorphisms and serum 25-hydroxyvitamin D levels with generalized vitiligo. $\mathrm{Br} \quad J$ Dermatol. 2012;167:815-821. doi:10.1111/j.1365-2133.2012.11132.x

19. Köstner K, Denzer N, Koreng M, et al. Association of genetic variants of the vitamin $\mathrm{D}$ receptor (VDR) with cutaneous squamous cell carcinomas (SCC) and basal cell carcinomas (BCC): a pilot study in a German population. Anticancer Res. 2012;32:327-333.

20. Simon KC, Munger KL, Xing Y, Ascherio A. Polymorphisms in vitamin D metabolism related genes and risk of multiple sclerosis. Mult Scler. 2010;16:133-138. doi:10.1177/1352458509355069

21. Gordon KA, Tosti A. Alopecia: evaluation and treatment. Clin Cosmet Investig Dermatol. 2011;4:101-106. doi:10.2147/CCID.S10182

22. Trüeb RM. Systematic approach to hair loss in women. $J$ Dtsch Dermatol Ges. 2010;8:284-97, 284-98. doi:10.1111/j.1610-0387. 2010.07261.x

23. Köstner K, Denzer N, Müller CS, Klein R, Tilgen W, Reichrath J. The relevance of vitamin $\mathrm{D}$ receptor (VDR) gene polymorphisms for cancer: a review of the literature. Anticancer Res. 2009;29:3511-3536.

24. Fan HR, Lin LQ, Ma H, Li Y, Sun CH. Association between vitamin D receptor gene polymorphism (TaqI) and obesity in Chinese population. J Genet. 2015;94:473-478. doi:10.1007/s12041-015-0541-x

25. Haussler MR, Whitfield GK, Haussler CA, et al. The nuclear vitamin D receptor: biological and molecular regulatory properties revealed. $J$ Bone Miner Res. 1998;13:325-349. doi:10.1359/jbmr.1998.13.3.325

26. Malloy PJ, Wang J, Peng L, et al. A unique insertion/duplication in the VDR gene that truncates the VDR causing hereditary 1,25-dihydroxyvitamin D-resistant rickets without alopecia. Arch Biochem Biophys. 2007;460:285-292. doi:10.1016/j.abb.2006.09.027

27. Thompson CC, Sisk JM, Beaudoin GM. Hairless and Wnt signaling: allies in epithelial stem cell differentiation. Cell Cycle. 2006;5:19131917. doi:10.4161/cc.5.17.3189

28. Lengerke C, Schmitt S, Bowman TV, et al. BMP and Wnt specify hematopoietic fate by activation of the Cdx-Hox pathway. Cell Stem Cell. 2008;2:72-82. doi:10.1016/j.stem.2007.10.022

29. Archbold HC, Yang YX, Chen L, Cadigan KM. How do they do Wnt they do?: regulation of transcription by the Wnt/ $\beta$-catenin pathway. Acta Physiol (Oxf). 2012;204:74-109. doi:10.1111/j.1748-1716.2011.02293.x

30. Lee J, Tumbar T. Hairy tale of signaling in hair follicle development and cycling. Semin Cell Dev Biol. 2012;23:906-916. doi:10.1016/j. semcdb.2012.08.003

31. Millar SE. Molecular mechanisms regulating hair follicle development. J Invest Dermatol. 2002;118(2):216-225

32. Adam RC, Yang H, Ge Y, et al. Temporal layering of signaling effectors drives chromatin remodeling during hair follicle stem cell lineage progression. Cell Stem Cell. 2018;22:398-413. doi:10.1016/j. stem.2017.12.004

\section{Publish your work in this journal}

Clinical, Cosmetic and Investigational Dermatology is an international, peer-reviewed, open access, online journal that focuses on the latest clinical and experimental research in all aspects of skin disease and cosmetic interventions. This journal is indexed on CAS.
The manuscript management system is completely online and includes a very quick and fair peer-review system, which is all easy to use. Visit http://www.dovepress.com/testimonials.php to read real quotes from published authors. 